Proc. Estonian Acad. Sci. Biol. Ecol., 2005, 54, 3, 171-189

\title{
Bottom topography and sediment lithology in two small lakes in Estonia
}

\author{
Jaanus Terasmaa \\ Institute of Ecology, Tallinn University, Kevade 2, 10137 Tallinn, Estonia; jaanus@eco.edu.ee \\ Received 31 August 2004, in revised form 23 December 2004

\begin{abstract}
In small lakes $(<10 \mathrm{ha})$ the process of sedimentation is not influenced very strongly by wind and wave activity and spatio-temporal variations in the composition of sediments are related with the topography of the current basin. Investigations on surface sediments (LOI, grain-size composition) in two small Estonian lakes - Lake Viitna Linajärv and Lake Väike Juusa - showed that up to $50 \%$ of the lithological composition of sediment is determined by the slope inclination, distance to the shore, and water depth. A composite dimensionless parameter $(C P)$ developed enables to use the same approach to the description of the location of the site in lakes of different size, bottom topography, and hypsographic curve. Using the $C P$ value it is possible to estimate the location of the sampling site in either an accumulation area (A area) or erosion-transportation area $(\mathrm{E}+\mathrm{T}$ area) with $\mathrm{A}<C P=2.5 \pm 0.5<\mathrm{E}+\mathrm{T}$.
\end{abstract}

Key words: small lakes, lake sediment, textural analysis, grain size, slope inclination, composite parameter.

\section{INTRODUCTION}

Lake sediments are natural archives that provide long-term records of past changes in climate-catchment processes as well as changes in biological communities in lakes. As to its origin, the material deposited in lakes is either autochthonous (formed in situ) or allochthonous (transported into the lake from outside) (Håkanson \& Jansson, 1983). The bulk of the (organic) material in the sediment has formed in the lake itself, mainly in the trophogenic water layer in the course of plant life; however, also the vegetation outside the lake is of rather great importance. The organic material can have a significant role in the ecology of the lake. Studies show that the mobilization of this material in the ice-free period happens very often, also organic material, especially nutrients, influences 
the productivity of micro- and macro-vegetation in lakes (Huttula, 1994; Wetzel, 1999).

On the basis of sediment composition and bottom morphometry of the lake, areas with different sedimentation regimes can be distinguished (Håkanson \& Jansson, 1983; Blais \& Klaff, 1995; Håkanson et al., 2000). The main areas are erosion, transportation, and accumulation areas. Erosion areas are most frequently in shallow waters and/or in deep slopes and are characterized by hard or consolidated deposit. The sediments within the areas of transportation are generally very variable - from sand to loose mud. The depositions within the accumulation areas are comparatively loose, with high water and organic content. Some authors (e.g. Blais \& Klaff, 1995) complement Håkanson's models and suggest that these should be reconsidered. An approach that distinguishes the area of accumulation and treats the area of transportation and accumulation as one is also used; the slope inclination is regarded as the best parameter for distinguishing the areas (Rowan et al., 1992; Blais \& Klaff, 1995; Terasmaa, 2001).

Sedimentation is affected by the vegetation in the lake - in addition to producing organic matter plants act as a barrier holding sediments on slopes. Besides plants inhibit the movement of water, and thus resuspension (Madsen et al., 2001). Therefore, an area that is classified as an area of erosion on the basis of other parameters may actually be an area of accumulation as an intensive accumulation of sediment occurs there due to the vegetation.

Gravitational movement of sediment is expressed as focusing, i.e. movement of sediment from shallower areas towards deeper ones, caused by water currents, especially during overturn (Likens \& Davis, 1975; Davis \& Ford, 1982). Focusing is most intensive in lake depressions with steep slopes but it also occurs in lakes with gently sloping bottoms (Blais \& Klaff, 1995). The intensity of sediment focusing may change over time (Davis \& Ford, 1982). The amount of matter accumulated yearly depends on water depth - the deeper an area is located, the greater the amount of matter deposited and the smaller the particles reaching it (fractionation of sediment is taking place) (Hilton et al., 1986; Rowan et al., 1992; Imboden \& Wüest, 1995; Chang et al., 2001). This phenomenon brings about uneven accumulation of sediment within the lake, providing a good basis for distinguishing areas with different sedimentation regimes (Lehman, 1975; Richard et al., 2001). Before the final accumulation of a settling particle its resuspension may take place. It has been found that up to $90 \%$ of the deposited material may have resuspended already earlier (Evans, 1994; Weyhenmeyer, 1996). The stability of the deposited material depends on its granulometric and lithological structure and on the binding and frictional force between particles, which has to be higher than the gravitational force for the sediment to stay on slopes (Dearing, 1997).

In shallow lakes with large areas wind affects sedimentation more than in small and deep lakes that have steeper slopes. In large lakes, where wind induced waves are acting strongly, a critical depth can be calculated. It is defined as the depth above which the critical shear stress for erosion is exceeded (Huttula, 1994). In small lakes wind and wave influence is not so important. To describe such 
difference, a dynamic ratio $D R\left(D R=S^{1 / 2} D_{\text {average }}{ }^{-1}\right.$, where $S$ is the lake area $\left(\mathrm{km}^{2}\right)$ and $D_{\text {average }}$ its average depth (m)) was developed by Håkanson \& Jansson (1983). It is regarded as a rather good diagnostic parameter for describing areas with different sedimentation regimes. The higher the $D R$ value, the greater the importance of taking into account the influence of the wind and waves on sedimentation. When $D R$ is very small $(<0.05)$, the slope inclinations are of great importance and the accumulation area in the lake is small. It has been proved that there exists a relationship between the value of $D R$ and the focusing of the sediment (Håkanson \& Jansson, 1983; Weyhenmeyer et al., 1995; Lindström et al., 1999). Studies in Estonian small lakes (Punning et al., 2002, 2003) show that in lakes of small dynamic ratio the flux of the resuspension of deposited particles is relatively small. The role of resuspension is greater below the thermocline and is mainly determined by the near-bottom transport fluxes (focusing), which are stronger in areas with steeper slopes.

The present paper is an attempt to find regularities in the formation of sediments in small Estonian lakes of different shape and bottom topography located in different landscape regions. To do this, a composite parameter developed for the description of the sampling site is used.

\section{STUDY AREA}

Sediment formation in two small lakes - Lake Viitna Linajärv (hereafter L. Linajärv) $\left(59^{\circ} 27^{\prime} \mathrm{N}\right.$ and $\left.25^{\circ} 01^{\prime} \mathrm{E}\right)$ and Lake Väike Juusa (hereafter L. Juusa) $\left(58^{\circ} 03^{\prime} \mathrm{N}\right.$ and $26^{\circ} 30^{\prime} \mathrm{E}$ ) (Fig. 1) is treated. The lakes studied are located in different landscapes with different land-use patterns and have different bottom topography.

Lake Linajärv is situated in Lahemaa National Park in northern Estonia. The surrounding territory features limno- and glaciofluvial sediments. The water level of the lake is $75 \mathrm{~m}$ a.s.l.; the difference between relative heights in the catchment area is from 15 to $20 \mathrm{~m}$. In the immediate vicinity of the lake the topography is quite level, higher landforms can be found in the western corner of the catchment. Steep eskers flank the lake to the west and south. The catchment area, excluding the lake, is 38 ha. Lake Linajärv has no outlet or inlet and the water level is controlled mainly by groundwater. As far as is known, land was never tilled close to the lake due to the thin humus layer of the soils. However, in recent decades human impact on the lake has been noticeable as a motel and saunas have been built on the lakeshore. Until the middle of the 20th century the lake was used for flax retting. The forest in the catchment area of the lake is mostly pine-dominated heath forest. Marshy areas occur at the northern tip of the lake. Lake Linajärv is a dimictic eutrophicated lake with an area of 3.8 ha (length $350 \mathrm{~m}$, maximum width $170 \mathrm{~m}$ ) and is elongated from north to south (Fig. 1c, Table 1). The lake has an average depth of $1.8 \mathrm{~m}$ with a maximum depth of $5 \mathrm{~m}$ in the southern end. The mean depth of the northern part of the lake is $1-2 \mathrm{~m}$. 


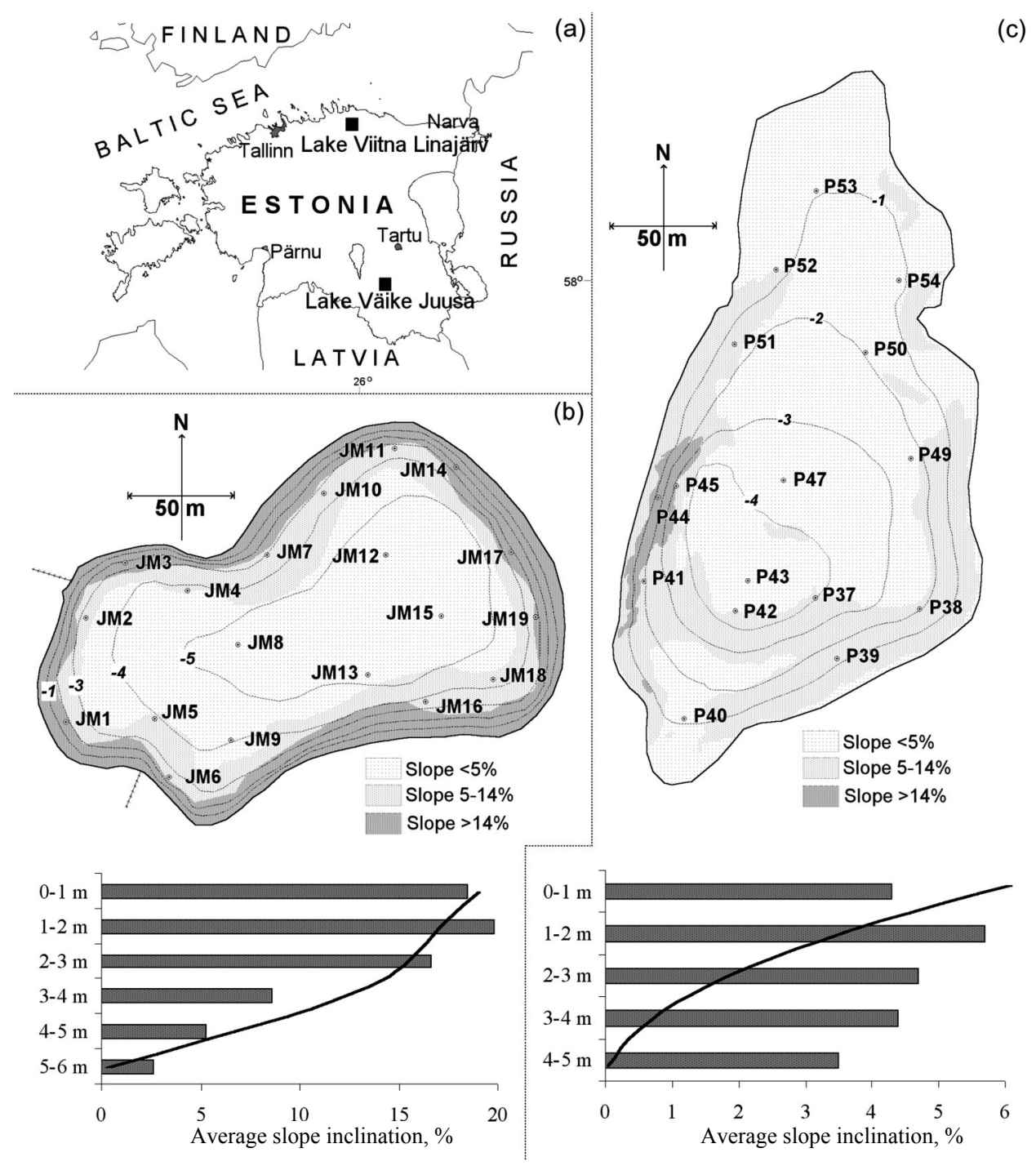

Fig. 1. (a) Locations of the study sites; (b) bathymetry and slope inclinations, average slope inclinations (grey columns), and hypsographic curve of L. Juusa; (c) bathymetry and slope inclinations, average slope inclinations (grey columns), and hypsographic curve of L. Linajärv.

Lake Linajärv is a lake with a convex hypsographic curve (Fig. 1c), in which the wind and waves have a rather modest impact on sedimentation $(D R=0.11)$. The northern part of the lake forms a relatively separated system (Fig. 1c) from which matter fluxes to other parts of the lake are apparently not very large. In addition to the bathymetric curve, Fig. 1 shows the variation of average slope inclinations. The smallest slope inclinations in L. Linajärv occur at depths of 4-5 $\mathrm{m}$ and $0-1 \mathrm{~m}$, and the largest at $1-2 \mathrm{~m}$. The occurrence of the largest slope 
Table 1. Characteristics of L. Linajärv and L. Juusa

\begin{tabular}{lcc}
\hline \multicolumn{1}{c}{ Characteristic } & L. Linajärv & L. Juusa \\
\hline Area $(S), \mathrm{m}^{2}$ & 38000 & 30000 \\
Volume $(V), \mathrm{m}^{3}$ & 69000 & 111300 \\
Perimeter $(P), \mathrm{m}$ & 870 & 710 \\
Maximum depth $\left(D_{\text {max }}\right), \mathrm{m}$ & 4.8 & 5.8 \\
Average depth $\left(D_{\text {average }}\right)^{*}, \mathrm{~m}$ & 1.8 & 3.7 \\
Maximum length $(L), \mathrm{m}$ & 350 & 250 \\
Maximum width $(W), \mathrm{m}$ & 170 & 160 \\
Average slope inclination $\left(S I_{\text {average }}\right), \%$ & 5 & 12 \\
Dynamic ratio $(D R)^{* *}$ & 0.11 & 0.04 \\
Form factor $\left(V_{d}^{-1}\right)^{* * *}$ & 0.91 & 0.49 \\
Length/width ratio $(L / W)$ & 2.1 & 1.6 \\
& & \\
$* \quad D_{\text {average }}=V S^{-1}$. & & \\
$* * \quad R^{1 / 2} D_{\text {average }}{ }^{-1}$. & & \\
$* * * V_{d}^{-1}=D_{\text {max }}\left(3 D_{\text {average }}\right)^{-1}$. & &
\end{tabular}

inclinations at this depth is mainly due to the transition between the shallower northern part of the lake and deeper southern part and steeper slopes in the southwestern part.

Lake Juusa is situated in the hilly central part of the Otepää Heights in southern Estonia in the territory of Otepää Nature Park. The water level of the lake is $122 \mathrm{~m}$ a.s.l. The difference between relative heights in the catchment area is nearly $60 \mathrm{~m}$; close to the lake the relative heights are within $20 \mathrm{~m}$. The northeastern and eastern shores are the steepest. The ca $2 \mathrm{~m}$ high terrace surrounding the lake refers to past rather great fluctuations in the water level. The lake is situated in semi-open cultural landscape, to the south and south-east are two farms while the northern slope is open pastureland. The western side of the lake is surrounded by a paludified area. The forests are birch-dominated, close to the lake alder and willow are widespread. One small ditch drains into the lake and one ditch drains out of the lake. Lake Juusa has an area of 3 ha (Table 1) and its longitudinal axis is east-west oriented. The deepest place in the lake $(5.8 \mathrm{~m})$ is in its eastern part (Fig. 1b). Practically the whole lake reaches a depth of 3-4 m rather close to the shore, the rest of the bottom is relatively gentle-sloped and level.

Lake Juusa is characterized by a concave hypsographic curve (Fig. 1b) and by very small dynamic ratio $(D R=0.04)$. Differently from L. Linajärv, the bottom of L. Juusa has a relatively regular shape - rapid deepening occurs everywhere in the near-shore zone, the deep area is large and has gentle slopes. Figure $1 \mathrm{~b}$ presents also average slope inclinations by depth, which confirm what is shown by the hypsographic curve: the greatest slope inclinations (reaching 20\%) occur at depths from 0 to $3 \mathrm{~m}$. Deeper slope inclinations decrease rapidly and at depths 5-6 m they are on average only $2 \%$. 


\section{MATERIALS AND METHODS}

Using the measurement results of contemporary lake bottom topography digital height models were constructed with the help of the programs MapInfo Professional 5.5 and VerticalMappert 2.5. These models can be used to calculate the volume of the lake, average depth, slope inclinations, etc. Also two parameters characterizing the sampling sites (slope inclination and distance to the shore) were calculated using these programs. Slope inclination was determined as the mean value for an area with a diameter of $6 \mathrm{~m}$ surrounding the sampling site to reduce the effect of possible random variation in the course of interpolation on the determination of slope inclinations.

Sediment sampling was performed with a Livingstone-Vallentine type piston corer and a gravity corer modified at the Institute of Ecology. Samples of $10 \mathrm{~cm}$ thickness were taken from the surface layers of sediment and packed into hermetic plastic boxes. In L. Juusa 19 samples and in L. Linajärv 16 samples were taken from the water-sediment surface (Fig. 1b, c; Tables 2 and 3).

Table 2. Morphometric characteristics of sampling sites and lithological composition of sediment in L. Linajärv. Summary: minimum (Min), first quartile (Q1), median (M), third quartile (Q3), and maximum (Max) values

\begin{tabular}{l|c|c|c|c|c|c}
\hline Site & $\begin{array}{c}\text { Depth }(D), \\
\mathrm{m}\end{array}$ & $\begin{array}{c}\text { Slope } \\
\text { inclination }(S I), \\
\%\end{array}$ & $\begin{array}{c}\text { Distance to } \\
\text { shore }(D S), \\
\mathrm{m}\end{array}$ & $\begin{array}{c}\text { Dry matter, } \\
\%\end{array}$ & $\begin{array}{c}\text { Mineral matter, } \\
\%\end{array}$ & $\begin{array}{c}\text { Sand fraction, } \\
\%\end{array}$ \\
\hline P37 & 4.1 & 5.7 & 48 & 1.6 & 19.7 & 32.9 \\
P38 & 2.3 & 7.2 & 19 & 3.4 & 36.8 & 67.3 \\
P39 & 1.6 & 7.8 & 18 & 61.0 & 98.2 & 99.7 \\
P40 & 1.1 & 4.0 & 17 & 5.9 & 38.2 & 60.9 \\
P41 & 2.05 & 10.5 & 11 & 6.1 & 52.7 & 71.2 \\
P42 & 4.9 & 5.1 & 54 & 1.7 & 20.2 & 45.3 \\
P43 & 4.4 & 0.4 & 59 & 1.6 & 18.8 & 30.8 \\
P44 & 1.8 & 22.3 & 8 & 44.6 & 95.6 & 99.6 \\
P45 & 2.35 & 18.8 & 15 & 6.2 & 60.2 & 94.3 \\
P47 & 3.9 & 1.5 & 61 & 1.8 & 19.9 & 39.5 \\
P49 & 2.2 & 4.3 & 31 & 4.9 & 48.1 & 76.5 \\
P50 & 1.9 & 3.1 & 31 & 13.1 & 76.8 & 92.0 \\
P51 & 1.8 & 6.3 & 15 & 3.9 & 36.2 & 71.3 \\
P52 & 1.3 & 5.2 & 19 & 3.0 & 24.7 & 44.2 \\
P53 & 0.9 & 1.8 & 36 & 2.4 & 25.0 & 61.8 \\
P54 & 1.35 & 2.0 & 20 & 5.6 & 57.9 & 90.9 \\
\hline Summary & \multicolumn{5}{|c}{} & \\
\hline Min & 0.9 & 0.4 & 8 & 1.6 & 18.8 & 30.8 \\
Q1 & 1.5 & 2.8 & 17 & 2.3 & 23.6 & 45.0 \\
M & 2.0 & 5.2 & 20 & 4.4 & 37.5 & 69.3 \\
Q3 & 2.7 & 7.4 & 39 & 6.1 & 58.5 & 91.2 \\
Max & 4.9 & 22.3 & 61 & 61.0 & 98.2 & 99.7 \\
\end{tabular}


Table 3. Morphometric characteristics of sampling sites and lithological composition of sediment in L. Juusa. Summary: minimum (Min), first quartile (Q1), median (M), third quartile (Q3), and maximum (Max) values

\begin{tabular}{|c|c|c|c|c|c|c|}
\hline Site & $\underset{\mathrm{m}}{\operatorname{Depth}(D)}$ & $\begin{array}{c}\text { Slope } \\
\text { inclination }(S I), \\
\% \\
\end{array}$ & $\begin{array}{c}\text { Distance to } \\
\text { shore }(D S) \text {, } \\
\mathrm{m}\end{array}$ & Dry matter, & $\begin{array}{c}\text { Mineral matter, } \\
\%\end{array}$ & $\begin{array}{c}\text { Sand fraction, } \\
\%\end{array}$ \\
\hline JM1 & 1.9 & 15.8 & 8.8 & 17.1 & 35.3 & 41.3 \\
\hline JM2 & 3.2 & 7.4 & 12.7 & 10.5 & 42.6 & 30.9 \\
\hline JM3 & 2.4 & 26.9 & 7.0 & 13.1 & 36.8 & 44.0 \\
\hline JM4 & 4.1 & 6.0 & 16.8 & 9.4 & 47.0 & 30.3 \\
\hline JM5 & 3.6 & 5.5 & 25.8 & 7.9 & 32.9 & 31.6 \\
\hline JM6 & 2.1 & 10.6 & 6.6 & 13.1 & 23.2 & 49.4 \\
\hline JM7 & 3.4 & 12.7 & 15.2 & 11.6 & 54.1 & 54.0 \\
\hline JM8 & 5.1 & 1.1 & 43.3 & 9.5 & 47.9 & 10.5 \\
\hline JM9 & 4.0 & 3.4 & 28.4 & 8.9 & 43.0 & 30.7 \\
\hline JM10 & 3.5 & 8.4 & 16.4 & 8.7 & 50.9 & 34.1 \\
\hline JM11 & 3.0 & 15.6 & 10.6 & 27.0 & 80.1 & 52.0 \\
\hline JM12 & 5.5 & 1.6 & 58.0 & 10.2 & 57.3 & 18.9 \\
\hline JM13 & 5.1 & 3.5 & 32.5 & 7.8 & 53.0 & 18.3 \\
\hline JM14 & 2.8 & 23.7 & 7.4 & 21.5 & 79.2 & 63.0 \\
\hline JM15 & 5.5 & 1.7 & 57.5 & 12.7 & 55.4 & 17.1 \\
\hline JM16 & 3.7 & 11.8 & 16.6 & 13.0 & 67.1 & 69.1 \\
\hline JM17 & 3.8 & 17.4 & 14.1 & 29.2 & 85.5 & 88.9 \\
\hline JM18 & 4.1 & 5.8 & 26.7 & 9.8 & 53.6 & 25.2 \\
\hline JM19 & 3.4 & 14.5 & 14.0 & 32.4 & 86.1 & 88.2 \\
\hline \multicolumn{7}{|c|}{ Summary } \\
\hline Min & 1.9 & 1.1 & 7 & 7.8 & 23.2 & 10.5 \\
\hline Q1 & 3.1 & 4.5 & 12 & 9.5 & 42.8 & 27.8 \\
\hline $\mathrm{M}$ & 3.6 & 8.4 & 16 & 11.6 & 53.0 & 34.1 \\
\hline Q3 & 4.1 & 15.1 & 28 & 15.1 & 62.2 & 53.0 \\
\hline Max & 5.5 & 26.9 & 58 & 32.4 & 86.1 & 88.9 \\
\hline
\end{tabular}

The mixed samples were processed using standard methods (Bengtsson \& Enell, 1986; Boyle, 2001). First the wet mass at a fixed volume was measured, then the samples were dried at $105^{\circ} \mathrm{C}$ to constant mass and the dry mass was calculated. Thereafter the samples were kept in a previously weighed crucible in a muffle furnace at $550^{\circ} \mathrm{C}$ and $950{ }^{\circ} \mathrm{C}$ for $3.5 \mathrm{~h}$. Next the samples were weighed and the loss on ignition (LOI) as well as the concentration of the mineral component and carbonates were determined. The calculations were made following generally used standard methods. In L. Linajärv the sediment had practically no carbonaceous component (i.e. it was mainly allogenic mineral matter); in L. Juusa, on the contrary, carbonaceous matter constituted up to $67 \%$ of the dry matter. To get better material for comparison, in the case of L. Juusa sediment the content of 
carbonates was subtracted from the amount of sediment and the proportions of mineral and organic matter were determined again on a $100 \%$ scale.

The granulometric composition of sediment samples was determined by wet sieving. Four metallic woven mesh sieves $(36,63,100$, and $315 \mu \mathrm{m})$ were stacked vertically and placed in a Vibratory Sieve Shaker "Analysette 3" PRO. A weighed subsample of sediment was placed into the upper sieve and after a suitable period of shaking (generally 15-20 min), the content of each sieve was weighed. Particle size partitioning was determined from the amount of sediment remaining in each specific sieve (Folk, 1980; Last, 2001). Grain-size fractions were amalgamated into two groups: sand $(>63 \mu \mathrm{m})$ and silt and clay $(<63 \mu \mathrm{m})$ according to the Udden-Wentworth grain-size scale (Last, 2001). Cartographic analysis and visualization were made with MapInfo Professional 5.5 and VerticalMapper 2.5.

The parameters describing the sampling sites were transformed into dimensionless units to enable to compare lakes of different size and shape in the same scale. To estimate the combined effect of parameters describing different sampling sites a composite parameter $C P$ was found (Terasmaa, 2004):

$$
C P=\sqrt{\frac{D_{\mathrm{r}} \times S I_{\mathrm{r}}}{D S_{\mathrm{r}}}},
$$

where $D_{\mathrm{r}}$ is the relative depth at the sampling site, $S I_{\mathrm{r}}$ is the relative slope inclination at the sampling site, and $D S_{\mathrm{r}}$ is the relative distance of the sampling site to the shore. The relative depth $\left(D_{\mathrm{r}}\right)$ was found as:

$$
D_{\mathrm{r}}=\sqrt{D \times \frac{D_{\max }}{D_{\text {average }} \times 3}},
$$

where $D$ is the water depth at the sampling site $(\mathrm{m})$ and $D_{\text {average }}$ is the average depth of the lake $(\mathrm{m})$. The quotient of the maximum depth to the average depth multiplied by 3 is according to Håkanson \& Jansson (1983) the so-called form factor $V_{\mathrm{d}}^{-1}$. The relative slope inclination $\left(S I_{\mathrm{r}}\right)$ is found by Eq. 3:

$$
S I_{\mathrm{r}}=\sqrt{S I},
$$

where $S I$ is the mean slope inclination in the area with a diameter of $6 \mathrm{~m}$ surrounding the sampling site (\%). The relative distance to the shore $D S_{\mathrm{r}}$ is found from Eq. 4: 


$$
D S_{\mathrm{r}}=\sqrt{\frac{D S \times L}{R_{\mathrm{A}} \times W}},
$$

where $D S$ is the distance of the sampling site to the nearest shore (m), $L$ is the maximum length of the lake $(\mathrm{m}), R_{\mathrm{A}}$ is the radius of a ring having an equal area with the lake (m), and $W$ is the maximum width of the lake $(\mathrm{m})$.

\section{RESULTS AND DISCUSSION}

\section{Sediment composition in L. Linajärv}

Analysis of the spatial distribution of the components in 16 surface sediment samples from L. Linajärv revealed quite high variation of dry matter, allogenic mineral matter as well as of matter in the sand fraction in the surface sediments (Table 2). Dry matter showed highest variation; in addition, its median differed from the mean value more than twice, which means that in the majority of sampling sites the content of dry matter was very low. Sampling sites P39 and P44 with their several times higher content of dry matter differed especially notably from the rest of the sampling sites. These sites are situated rather near to the shore on steep slopes. The smallest concentrations of dry matter were recorded in samples taken from the deepest areas of the lake (P47, P42, P37, P43) (Fig. 1c). Besides, a low concentration of dry matter was observed also in the northern tip of the lake (P53), where water is shallow and the slope is very gentle. In the majority of sampling sites the content of dry matter was in the range $3-10 \%$.

The variation of mineral matter in the surface sediments follows the same pattern as the dry matter variation (Table 2). The relationship between these two components is strong in the case of L. Linajärv (0.98). Differences are greater at site P45 and, to a smaller extent also at site P38, where the dry matter content is low but the content of mineral matter is relatively high. These sampling sites are located at approximately the same depth and the same distance from the shore, being apparently in the transition zone between the areas of erosion and accumulation where sedimentation is relatively unstable.

Figure 2a presents the grain size distribution of mineral matter. The sector diagram, whose diameter indicates the content of mineral matter in dry matter, distinguishes clearly sites P39 and P44 with high mineral matter contents. The same sites also have the highest proportion of sand. The sand fraction predominates also at sites P50 and P54, and to a smaller extent at P41, P49, and P51. The lowest proportions of mineral matter (the sediment is richer in organic matter) can be found mostly in the deepest part of the lake where fine-grained material predominates, but also at the northern tip of the lake. Analogous results on 


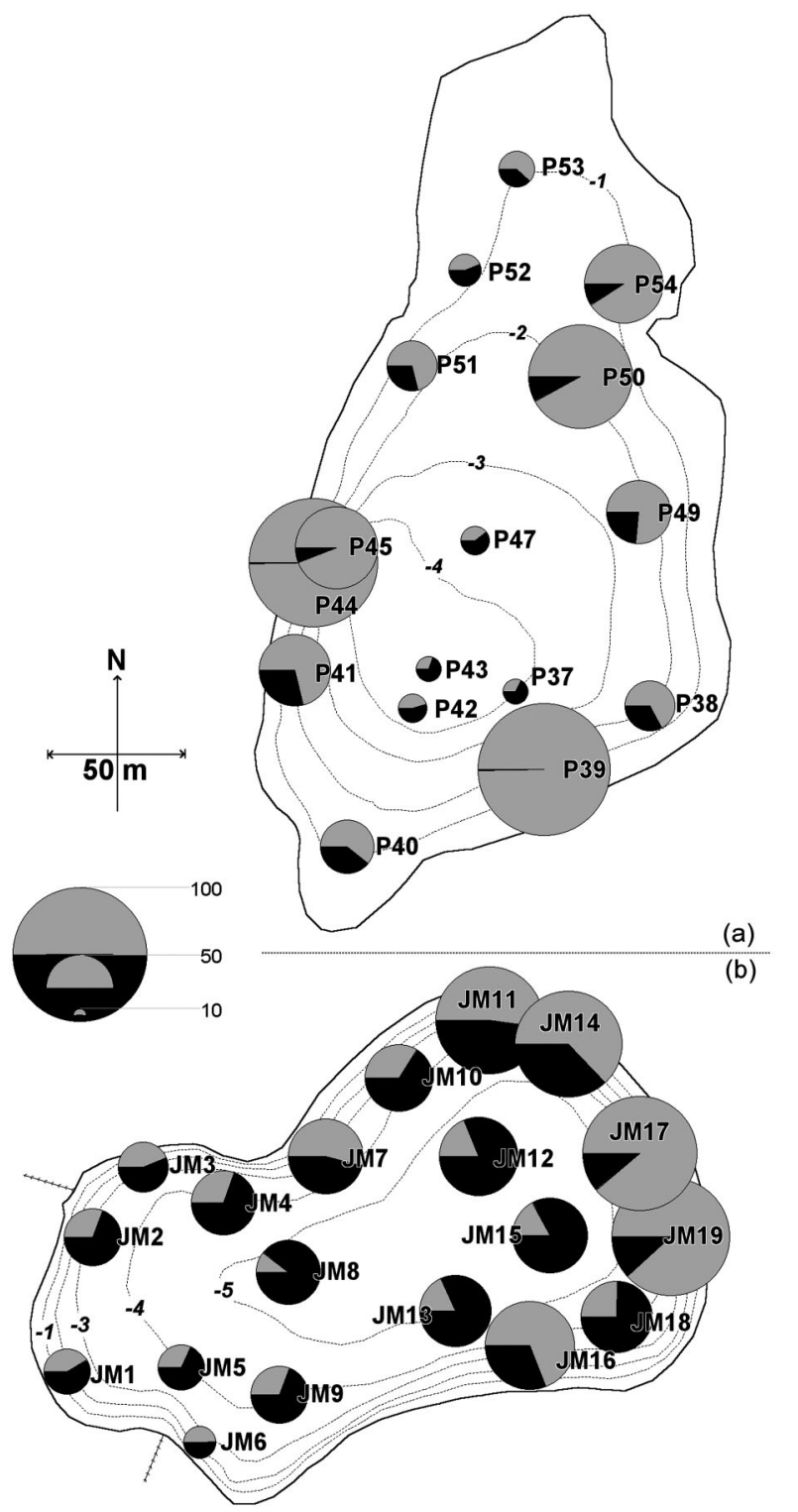

Fig. 2. Sand (grey) and silt and clay (black) fractions in the samples from (a) L. Linajärv and (b) L. Juusa. The diameters of the pies denote the content of allogenic mineral matter in \% scale. Dotted lines indicate lake depth.

L. Linajärv were also obtained by analysis of temporally older samples (Punning et al., 2004), which revealed statistically significant relationships between the ratio of mineral and organic matter and the parameters determining the sampling site's location. 


\section{Sediment composition in L. Juusa}

The slope inclinations of L. Juusa are high through the whole shoreline, therefore the area of shallow water is small and with steep slopes. For this reason the spatial distribution of the composition of surface sediment in this lake is more strongly connected with the bottom topography than with the other parameters.

The composition of the 19 samples taken from the surface sediment of L. Juusa varied largely due to the slope inclination (Table 3). The content of dry matter in the sediment was from $7.8 \%$ to $32.4 \%$ with sampling sites with dry matter content of $10-20 \%$ making up the largest group. In four sampling sites (JM19, JM17, JM11, JM14) the dry matter content was over $20 \%$. All these sites were located on rather steep slopes and not far from the eastern or northeastern shore of the lake (see Fig. 1b). It should be noted here that such distribution may partly be due to the characteristics of the landscape around the lake. It was shown that the amount of terrigenous material reaching a lake depends on the composition of the soil and vegetation (Genereux \& Bandopadhyay, 2001). At the same time in the composition of the mineral material in L. Juusa authigenic carbonaceous component is of rather great importance, its distribution in the surface sediments is quite uniform and does not depend on the bottom topography of the lake. The next large group of sampling sites (JM1, JM3, JM6, JM16, JM7, JM2), where the dry matter content is within the interval of $10-20 \%$, is also located close to the shore in an area with a high slope inclination. Sampling sites with lower dry matter concentrations $(>10 \%)$ are mainly in deeper parts of the lake with gentler slopes. The only exceptions are sites JM12 and JM15, which are located in the deepest part of the lake but in its eastern area and not far from a steep slope.

The spatial distribution of mineral matter and its grain-size composition in the surface sediment of L. Juusa reveal predominantly the same tendencies as the dry matter distribution: the highest values were recorded in the near-shore zones in the eastern and northeastern parts of the lake (Table 3, Fig. 2b). The relationship between the content of mineral and dry matter is average (0.47). In the majority of sampling sites the proportion of mineral matter fell between $40 \%$ and $50 \%$. The proportion of the sand fraction varied more notably with higher values occurring mainly in the near-shore sampling sites, lower values in deeper areas. Again sites JM12 and JM15 stand out with their relatively high content of dry matter and more abundant coarse-grained material than could be expected considering the location parameters of the lake. Most probably this material has been transported to the deepest part of the lake from areas closer to the shore in the course of focusing. Therefore, it should always be considered what kind of conditions prevail not only at the sampling site but also at some distance from it, especially if there occur steep slopes, which cause greater transport of sediment to deeper areas and its accumulation there (Hilton et al., 1986). The lowest content of mineral matter was observed at sampling sites JM6 and JM5 although in the 
former the level was still relatively high. This may be caused by the impact of the ditch flowing into the lake as this site is located quite close to the mouth of the ditch. As the ditch starting from a sauna flows through marshy areas at some length, it presumably contains nutrients and organic matter rather than mineral matter, which are carried into the lake, and the composition of the sediment reflects it. Analysis of macrofossils (Koff, 2004) showed that at sites JM6 and JM5 the sediment contains very large amounts of wood (mainly twigs) for this part of the lake, which also increases the share of organic matter. In general, the proportion of organic matter is higher in this part of the lake than elsewhere. While the sediments in the eastern and northeastern parts of the lake have larger mineral matter content (also at greater depths) then in its western and southwestern parts organic matter is relatively more abundant and the sediment also contains larger amounts of fine-grained material.

\section{Comparison of the lakes}

Although the maximum depths and areas of L. Linajärv and L. Juusa are not very different, their bottom topographies differ greatly (Fig. 1b, c), as a result of which e.g. the volume of L. Juusa is 1.6 as large as that of L. Linajärv. To describe the effect of the parameters of the location of the sampling site (slope inclination, water depth, distance to the shore) on the formation of the sediment composition, these parameters were transformed to relative values (see Eqs. 1-4), and below we operate with relative depth $D_{\mathrm{r}}$, relative slope inclination $S I_{\mathrm{r}}$, and relative distance to the shore $D S_{\mathrm{r}}$.

As the minimum, maximum, median, and first and third quartile values of the relative parameters of the sampling sites given in Table 4 (also see Table 1) show, in some cases there are rather large differences between the two lakes. The maximum relative depth $D_{\mathrm{r}}$ is greater in L. Linajärv than in L. Juusa, which is caused by the former's smaller mean depth and greater form factor (the bathymetric curve is more linear). The median relative slope inclination $S I_{\mathrm{r}}$ is greater

Table 4. Five-number summary of the relative parameters and the composite parameter of the sampling sites of L. Linajärv and L. Juusa $\left(D_{\mathrm{r}}-\right.$ relative depth, $S I_{\mathrm{r}}-$ relative slope inclination, $D S_{\mathrm{r}}$ - relative distance to the shore, $C P$ - composite parameter) (see Eqs. 1-4)

\begin{tabular}{l|c|c|c|c|c|c|c|c}
\hline & \multicolumn{4}{|c|}{ L. Linajärv } & \multicolumn{4}{c}{ L. Juusa } \\
\cline { 2 - 9 } & $D_{\mathrm{r}}$ & $S I_{\mathrm{r}}$ & $D S_{\mathrm{r}}$ & $C P$ & $D_{\mathrm{r}}$ & $S I_{\mathrm{r}}$ & $D S_{\mathrm{r}}$ & $C P$ \\
\hline Minimum & 0.90 & 0.61 & 0.39 & 1.08 & 0.96 & 1.05 & 0.32 & 1.42 \\
1st quartile & 1.18 & 1.67 & 0.56 & 1.71 & 1.23 & 2.10 & 0.43 & 2.11 \\
Median & 1.34 & 2.28 & 0.60 & 2.11 & 1.33 & 2.90 & 0.51 & 2.75 \\
3rd quartile & 1.57 & 2.71 & 0.85 & 2.49 & 1.42 & 3.88 & 0.66 & 3.21 \\
Maximum & 2.11 & 4.72 & 1.07 & 3.95 & 1.64 & 5.18 & 0.96 & 4.10
\end{tabular}


in L. Juusa. The relative distance to the shore $D S_{\mathrm{r}}$ is somewhat greater in the case of L. Linajärv, as this lake has a larger area as well as a greater ratio of length to width $(L / W)$. The composite parameter has a larger value for L. Juusa. Here the decisive factor seems to be greater slope inclinations, which due to their great influence on the sedimentation process determine a large part of the $C P$ value.

To estimate the effect of different parameters on the sediment composition, a correlation matrix was compiled for both lakes (Table 5). As the matrix shows, the correlation coefficients between the lithological composition of the sediment and the parameters of the location of the sampling site were never very strong; however, strong relationships were found between the parameters themselves and between the contents of mineral and dry matter. In both cases the composite parameter was very strongly correlated with the relative slope inclination $(R=0.99)$. For L. Juusa the correlation was very strong or strong also with other relative parameters. For L. Linajärv, however, practically no correlation was found between $C P$ and the relative depth $D_{\mathrm{r}}$, which is due to the characteristics of the lake bottom. Although all relative parameters are part of the $C P$ value, they all have different influence on it according to the morphometric characteristics and the size of the lake.

Table 5. Spearman correlations between relative parameters of sampling sites and sediment composition in L. Linajärv and L. Juusa. $P$-values are given in parentheses, NS - not significant

\begin{tabular}{|c|c|c|c|c|c|c|c|c|c|c|c|c|}
\hline \multicolumn{7}{|c|}{ L. Linajärv } & \multicolumn{6}{|c|}{ L. Juusa } \\
\hline & के & $\breve{a}$ & 8 & 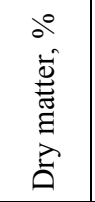 & 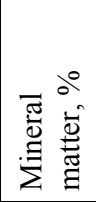 & 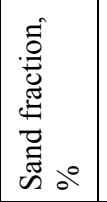 & 5 & 今 & 8 & 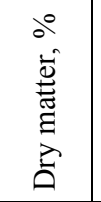 & 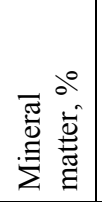 & 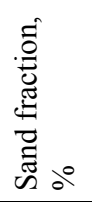 \\
\hline$D_{\mathrm{r}}$ & $\begin{array}{l}0.04 \\
(\mathrm{NS})\end{array}$ & $\begin{array}{r}0.44 \\
\text { (NS) }\end{array}$ & $\begin{array}{r}0.13 \\
(\mathrm{NS})\end{array}$ & $\begin{array}{r}-0.45 \\
(\mathrm{NS})\end{array}$ & $\begin{array}{r}-0.44 \\
(\mathrm{NS})\end{array}$ & $\begin{array}{r}-0.37 \\
(\mathrm{NS})\end{array}$ & $\begin{array}{c}-0.78 \\
(<0.01)\end{array}$ & $\begin{array}{c}0.91 \\
(<0.01)\end{array}$ & $\begin{array}{c}-0.80 \\
(<0.01)\end{array}$ & $\begin{array}{c}-0.52 \\
(<0.05)\end{array}$ & $\begin{array}{l}0.27 \\
(\mathrm{NS})\end{array}$ & $\begin{array}{c}-0.66 \\
(<0.01)\end{array}$ \\
\hline \multirow{2}{*}{$S I_{\mathrm{r}}$} & & -0.77 & 0.99 & 0.54 & 0.52 & 0.54 & & -0.85 & 0.99 & 0.75 & 0.22 & 0.86 \\
\hline & & $(<0.01)$ & $(<0.01)$ & $(<0.05)$ & $(<0.05)$ & $(<0.05)$ & & $(<0.01)$ & $(<0.01)$ & $(<0.01)$ & (NS) & $(<0.01)$ \\
\hline$D S_{\mathrm{r}}$ & & & $\begin{array}{l}-0.75 \\
(<0.01)\end{array}$ & $\begin{array}{c}-0.71 \\
(<0.01)\end{array}$ & $\begin{array}{c}-0.67 \\
(<0.01)\end{array}$ & $\begin{array}{l}-0.66 \\
(<0.01)\end{array}$ & & & $\begin{array}{c}-0.89 \\
(<0.01)\end{array}$ & $\begin{array}{c}-0.56 \\
(<0.05)\end{array}$ & $\begin{array}{l}0.17 \\
(\mathrm{NS})\end{array}$ & $\begin{array}{l}-0.67 \\
(<0.01)\end{array}$ \\
\hline$C P$ & & & & $\begin{array}{l}0.49 \\
\text { (NS) }\end{array}$ & $\begin{array}{l}0.47 \\
(\mathrm{NS})\end{array}$ & $\begin{array}{c}0.51 \\
(<0.05)\end{array}$ & & & & $\begin{array}{c}0.77 \\
(<0.01)\end{array}$ & $\begin{array}{l}0.18 \\
(\mathrm{NS})\end{array}$ & $\begin{array}{r}0.86 \\
(<0.01)\end{array}$ \\
\hline \multicolumn{2}{|c|}{$\begin{array}{c}\text { Dry mat- } \\
\text { ter, } \%\end{array}$} & & & & $\begin{array}{r}0.98 \\
(<0.01)\end{array}$ & $\begin{array}{c}0.91 \\
(<0.01)\end{array}$ & & & & & $\begin{array}{c}0.47 \\
(<0.05)\end{array}$ & $\begin{array}{c}0.72 \\
(<0.01)\end{array}$ \\
\hline \multicolumn{2}{|c|}{ Mineral } & & & & & $\begin{array}{r}0.96 \\
(<0.01)\end{array}$ & & & & & & $\begin{array}{l}0.38 \\
\text { (NS) }\end{array}$ \\
\hline
\end{tabular}


The correlation between the lithological composition of the sediment and the parameters of the location of the sampling sites is predominantly average or strong (Table 4). In the case of L. Linajärv this correlation was stronger with $S I_{\mathrm{r}}$ and $D S_{\mathrm{r}}$; however, also an average correlation was found with the composite parameter. In the case of L. Juusa the content of mineral matter showed significantly strong correlation with none of the parameters. The content of dry matter has average or strong correlations with all relative parameters and a strong correlation with the composite parameter $(R=0.77)$. In L. Juusa the strongest correlations with the relative location parameters of the sampling site were shown by the content of sand in the sediment; strong correlations were found with $S I_{\mathrm{r}}$ and $C P$ $(R=0.86)$ while $D_{\mathrm{r}}$ and $D S_{\mathrm{r}}$ had correlation of average strength.

A positive correlation between the content of mineral and dry matter and the grain-size distribution and $S I_{\mathrm{r}}$ means that in an area with a higher slope inclination the sediment contains more mineral matter and less water. Organic and finergrained mineral material has been transported to deeper places with gentler slopes. A negative correlation between the content of mineral matter, grain-size distribution, and $S I_{\mathrm{r}}$ can be explained by the longer distance from the shore (i.e. in a deeper area). Determination coefficients $\left(R^{2}\right)$ between the slope inclinations and sediment composition were on average 0.3 in the case of both lakes. This means that nearly $1 / 3$ of the content of the relevant component (dry or mineral matter) in the sediment is determined by the slope inclination. In the case of L. Linajärv also the distance to the shore is rather significant.

Thus, in the case of L. Juusa among the location parameters of the sampling sites slope inclinations are clearly the most important, but also the other two parameters (distance to the shore and water depth) are important. In the case of L. Linajärv depth is not very important, slope inclinations and distance to the shore are more important. However, statistical processing revealed in both lakes some sampling sites whose sediment composition did not coincide with the general trends. In L. Juusa site JM6, mentioned already earlier, stands out with its high content of organic matter in the sediment, which is not comparable to the values at other sites located under similar conditions (erosion and transportation area). In L. Linajärv even three sites - P49, P50, and P54 - did not agree with the general trends. All three are situated close to the gentle-sloped eastern shore, whose high mineral matter content may be slightly connected with the intensive use of the lake for swimming and scuba diving. Therefore the sediment composition is affected not only by the same factors as the remaining sites. These sites were excluded from the further analysis.

\section{Distribution of sedimentation areas by the composite parameter}

Using the $C P$ values it was possible to distinguish in both lakes sampling sites situated in the accumulation area (A area) and in the erosion and transportation area $(\mathrm{E}+\mathrm{T}$ area) and to draw borders between these areas (Fig. 3a; see Table 6). 
Table 6. Borders between the erosion and transportation areas ( $\mathrm{E}+\mathrm{T}$ area) and accumulation areas (A area) in L. Linajärv and L. Juusa (confidence level 0.95)

\begin{tabular}{l|cc|c|r}
\hline \multirow{2}{*}{ Characteristic } & \multicolumn{2}{|c|}{ L. Linajärv } & \multicolumn{2}{c}{ L. Juusa } \\
\cline { 2 - 5 } & $\mathrm{E}+\mathrm{T}$ area & A area & E + T area & A area \\
\hline Depth $(D), \mathrm{m}$ & $<2.3$ & $>1.3$ & $<3.5$ & $>4.0$ \\
Slope inclination $(S I), \%$ & $>5.1$ & $<5.4$ & $>11.0$ & $<5.2$ \\
Distance to shore $(D S), \mathrm{m}$ & $>18.7$ & $<25.0$ & $>14.9$ & $<23.4$ \\
Composite parameter $(C P)$ & $>2.3$ & $<2.2$ & $>3.0$ & $<2.3$ \\
Dry matter, \% & - & $<4.0$ & $>12.3$ & $<10.8$ \\
Mineral matter, \% & $>34.3$ & $<30.1$ & $>47.3$ & $<55.5$ \\
Sand fraction, \% & $>67.7$ & $<56.5$ & $>41.8$ & $<29.3$ \\
& & & & \\
- Data out of range. & & & &
\end{tabular}

Figure 3a presents the minimum, first quartile median, third quartile, and maximum values of all the samples; Table 6 gives the borders at 0.95 confidence level. In the case of L. Linajärv $C P>2.3$ for the sampling sites in the $\mathrm{E}+\mathrm{T}$ area and $C P<2.2$ in the A area at 0.95 confidence level. In the case of L. Juusa the values were respectively $C P>3.0$ and $C P<2.3$. Thus, generalizing the two lakes we can say that the border between the $\mathrm{E}+\mathrm{T}$ area and the $\mathrm{A}$ area is at the $C P$ value of $2.5 \pm 0.5$.

Based on the distribution of areas according to analysis of $C P$ values Fig. $3 \mathrm{~b}$ presents minimum, first quartile, median, third quartile, and maximum values of the content of sand fraction (\%) in the mineral matter in the respective sampling sites. In L. Linajärv the content of the sand fraction at the sampling sites in the $\mathrm{E}+\mathrm{T}$ area was $>68 \%$ and in the $\mathrm{A}$ area, $<57 \%$ at 0.95 confidence level (Table 6). For L. Juusa the difference between the content of sand between the sampling sites in the E $+\mathrm{T}$ area was greater; apparently this is due to less stable sedimentation conditions prevailing on steep slopes near the shore. In L. Juusa the content of the sand fraction was $>42 \%$ in the $\mathrm{E}+\mathrm{T}$ area and $<29 \%$ in the A area, confidence level 0.95 . As the grain size distribution is determined by the genesis of the sediment in the surrounding areas, it is impossible to set a uniform rule for both lakes and define a clear border between different sedimentation areas.

Using other parameters (Table 6) to a certain extent similar division can be made (the confidence level of the values in Table 6 is 0.95). However, in general it can be said that in L. Linajärv accumulation usually occurred at greater depths than 1.3-2.3 $\mathrm{m}$ (except the shallow northern tip), slope inclinations are less than $5 \%$, and the border of the A area is $\sim 20 \mathrm{~m}$ from the shore. The content of mineral matter in the accumulating material should be below $30 \%$ in this lake.

In L. Juusa the accumulation area begins from a depth of ca 3.5-4 m, slope inclinations from $5-10 \%$, and the border of the A area from a distance of about 


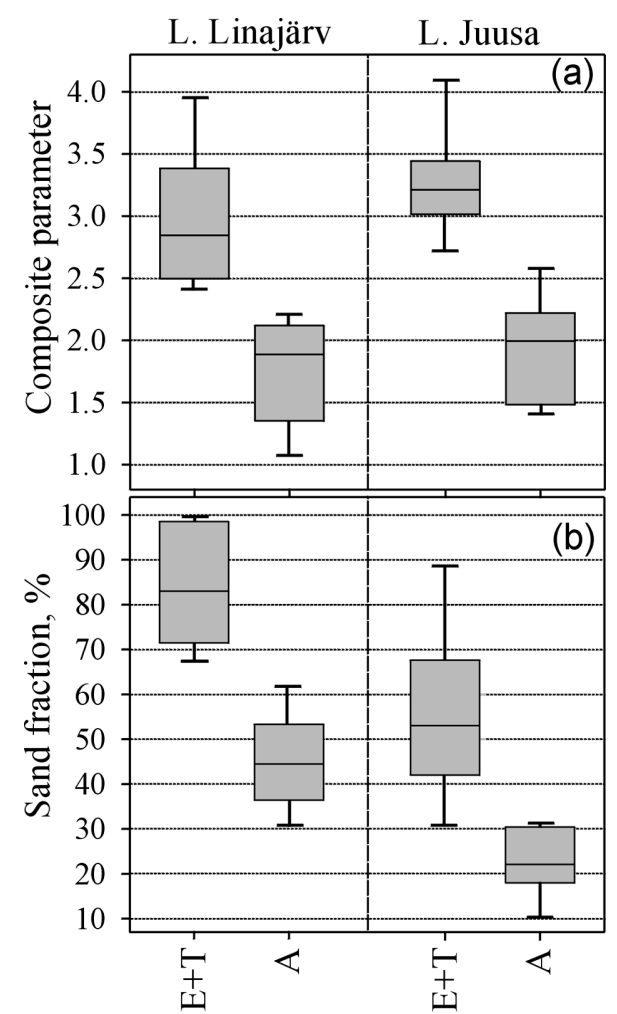

Fig. 3. Minimum, mean, and maximum values of (a) the composite parameter and (b) the content of sand fraction in L. Linajärv and L. Juusa $(\mathrm{E}+\mathrm{T}$ area-erosion and transportation area, A area - accumulation area).

$20 \mathrm{~m}$ to the shore (analogously to L. Linajärv). The content of dry matter in the sediment should be below $10 \%$ in the accumulation area and the content of mineral matter should be below 55\%; however, in the erosion and transportation area there were sampling sites where this value could be below $50 \%$.

\section{CONCLUSIONS}

In small lakes the dynamics of sedimentation is determined by bottom topography rather than wind and wave activities like in larger shallower lakes. However, the set of factors affecting this dynamics is still quite extensive and because of the small size of the lake the so-called random factors - large numbers of swimmers in summer, construction of a beach etc. - may be greater. One of the important factors affecting the composition and formation of sediment is bottom 
topography, which in a simplified form is described by the hypsographic curve. The course of this curve enables to draw some general conclusions about the location of sedimentation areas.

Our analysis showed that a composite parameter built on the basis of a limited number of more easily observable parameters of the location of the sampling site (depth, slope inclination, distance to the shore) determines, depending on the lake, up to a half of the variation in the composition of the sediments. At the same time each parameter alone is also of importance. In the lakes studied the most important autochthonous factor affecting sediment composition was slope inclination ( $R$ up to 0.86 ) and to a lesser extent, distance to the shore ( $R$ up to $-0.67)$.

Analysis of spatial variation of the composite parameter and changes in other parameters allows determining approximate borders of the accumulation area in L. Linajärv, a lake with a convex hypsographic curve - a site can be expected to be situated in the A area if $C P<2.2$ (confidence level 0.95); the proportion of the sand fraction is not over $56 \%$. In L. Juusa - a lake with a concave hypsographic curve - a site is located in the A area if $C P<2.3$ (confidence level 0.95) and the proportion of the sand fraction is generally below $29 \%$.

\section{ACKNOWLEDGEMENTS}

The study was supported by target-financed projects of the Estonian Ministry of Education and Research (0282/20502; D-402/13) and the Estonian Science Foundation (ETF-5584). The author would like to thank Professor Jaan-Mati Punning, colleagues from the Institute of Ecology, and students (especially Tiit Vaasma) of Tallinn University for their help.

\section{REFERENCES}

Bengtsson, L. \& Enell, M. 1986. Chemical analysis. In Handbook of Holocene Palaeoecology and Palaeohydrology (Berglund, B. E., ed.), pp. 423-451. John Wiley \& Sons, Chichester.

Blais, J. M. \& Klaff, J. 1995. The influence of lake morphometry on sediment focusing. Limnol. Oceanogr., 40, 582-588.

Boyle, J. F. 2001. Inorganic geochemical methods in palaeolimnology. In Tracking Environmental Change Using Lake Sediments. Vol. 2. Physical and Geochemical Methods (Last, W. M. \& Smol, J. P., eds.), pp. 83-141. Kluwer Academic Publishers, London.

Chang, Y. N., Scrimsahaw, M. D. \& Lester, J. N. 2001. A revised Grain-Sized Trend Analysis program to define net sediment transport pathways. Comput. Geosci., 27, 109-114.

Davis, M. B. \& Ford, M. S. 1982. Sediment focusing in Mirror Lake, New Hampshire. Limnol. Oceanogr., 27, 137-150.

Dearing, J. A. 1997. Sedimentary indicators of lake-level changes in the humid temperate zone: a critical review. J. Paleolimnol., 18, 1-14. 
Evans, R. D. 1994. Empirical evidence of the importance of sediment traps in a eutrophic holomictic lake. J. Paleolimnol., 5, 175-188.

Folk, R. L. 1980. Petrology of Sedimentary Rocks. Hemphill Publishing Company, Austin, Texas.

Genereux, D. \& Bandopadhyay, I. 2001. Numerical investigation of lake bed seepage patterns: effects of porous medium and lake properties. J. Hydrol., 241, 286-303.

Håkanson, L. \& Jansson, M. 1983. Principles of Lake Sedimentology. Springer-Verlag, Berlin.

Håkanson, L., Parparov, A. \& Hambright, K. D. 2000. Modelling the impact of water level fluctuations on water quality (suspended particulate mater) in Lake Kinneret, Israel. Ecol. Model., 128, $101-125$.

Hilton, J., Lishman, J. P. \& Allen, P. V. 1986. The dominant processes of sediment distribution and focusing in a small, eutrophic, monomictic lake. Limnol. Oceanogr., 31, 125-133.

Huttula, T. 1994. Suspended sediment transport in Lake Säkylän Pühajärvi. Aqua Fenn., 24, 171-185.

Imboden, D. M. \& Wüest, A. 1995. Mixing mechanisms in lakes. In Physics and Chemistry of Lakes (Lerman, A., Imboden, D. M. \& Gat, J. R., eds.), pp. 81-138. Springen-Verlag, Berlin.

Koff, T. 2004. Macrofossils in the sediment of L. Juusa (southern Estonia). In Estonia. Geographical Studies 9, pp. 30-41. Estonian Academy Publishers, Tallinn.

Last, W. M. 2001. Mineralogical analysis of lake sediments. In Tracking Environmental Change Using Lake Sediments. Vol. 2. Physical and Geochemical Methods, pp. 143-187. Kluwer Academic Publishers, London.

Lehman, J. T. 1975. Reconstructing the rate of accumulation of lake sediment: the effect of sediment focusing. Quat. Res., 5, 541-550.

Lindström, M., Håkanson, L., Abrahamsson, O. \& Håkanson, J. 1999. An empirical model for prediction of lake water suspended particulate matter. Ecol. Model., 121, 185-198.

Likens, G. E. \& Davis, M. B. 1975. Post-glacial history of Mirror Lake and its watershed in New Hampshire, U.S.A., initial report. Int. Ver. Theor. Angew. Limnol. Verh., 19, 982-993.

Madsen, J. D., Chambers, P. A., James, W. F., Koch, E. W. \& Westlake, D. F. 2001. The interaction between water movement, sediment dynamics and submersed macrophytes. Hydrobiologia, 444, 71-85.

Punning, J.-M., Koff, T., Alliksaar, T. \& Terasmaa, J. 2002. Tracing the pathways of seston into a small lake. Proc. Estonia Acad. Sci. Biol. Ecol., 51, 227-241.

Punning, J.-M., Terasmaa, J., Koff, T. \& Alliksaar, T. 2003. Seasonal fluxes of particulate matter in a small closed lake in northern Estonia. Water Air Soil Pollut., 149, 77-92.

Punning, J.-M., Alliksaar, T., Terasmaa, J. \& Jevrejeva, S. 2004. Recent patterns of sediment accumulation in a small closed eutrophic lake revealed by the sediment records. Hydrobiologia, 529, 71-81.

Richard, B., Renberg, I. \& Brännvall, M. L. 2001. A whole-basin study of sediment accumulation using stable lead isotopes and fly-ash particles in an acidified lake, Sweden. Limnol. Oceanogr., 46, 176-187.

Rowan, D. J., Kalff, J. \& Rasmussen, J. B. 1992. Estimating the mud deposition border depth in lakes from wave theory. Can. J. Fish. Aquat. Sci., 49, 2490-2497.

Terasmaa, J. 2001. Morfomeetriliste karakreristikute mõju sette kujunemisele mõningates Eesti väikejärvedes. Master's thesis, Tallinn Pedagogical University.

Terasmaa, J. 2004. Settimisrežiimi määravad tegurid ja nende analüüs kahes Eesti väikejärves. In Geoökoloogilisi uurimusi. Inst. Ecol. Publ., 8, 36-60. Tallinn.

Wetzel, R. G. 1999. Plants and water in and adjacent to lakes. In Eco-hydrology: Plants and Water in Terrestrial and Aquatic Environments (Baird, A. J. \& Wilby, R. L., eds.), pp. 269-299. Routledge, London.

Weyhenmeyer, G. A. 1996. The significance of sediment resuspension in lakes. Acta Univ. Upsal.

Weyhenmeyer, G. A., Meili, M. \& Pierson, D. C. 1995. A simple method to quantify sources of settling particles in lakes: resupension versus new sedimentation of material from planktonic production. Mar. Freshwater Res., 46, 223-231. 


\title{
Põhjatopograafia ja setete litoloogia kahes Eesti väikejärves
}

\begin{abstract}
Jaanus Terasmaa
Senised uuringud on näidanud, et väikejärvedes on sette kujunemine mõjutatud rohkem põhjatopograafia kui tuule/lainetuse poolt. Artiklis on püütud leida järvesetete formeerumise seaduspärasusi kahes erineva kuju ja põhjatopograafiaga väikejärves (Viitna Linajärv ja Väike Juusa järv), kasutades proovivõtukoha kirjeldamiseks välja töötatud koondparameetrit $C P$. Selleks koguti mõlema järve pindmistest setetest üle terve järve arvukalt proove, analüüsiti sette koostist ning leiti proovivõtukohta kirjeldavad parameetrid (veerukalle, veesügavus, kaugus kaldast). Läbiviidud analüüs näitas, et proovivõtukohta kirjeldavate parameetrite alusel leitud $C P$ määrab ära kuni poole sette koostise varieerumisest. $C P$ abil eraldati erinevate akumulatsioonialade (A) ning erosiooni- ja transpordialade $(\mathrm{E}+\mathrm{T})$ ligikaudsed piirid, mille järgi $\mathrm{A}<C P=2,5 \pm 0,5<\mathrm{E}+\mathrm{T}$.
\end{abstract}

